\title{
Induced Resistance to Blackleg (Leptosphaeria maculans) Disease of Canola (Brassica napus) Caused by a Weakly Virulent Isolate of Leptosphaeria biglobosa
}

\author{
Y. Chen and W. G. D. Fernando, Department of Plant Science, University of Manitoba, Winnipeg, MB, R3T 2N2, \\ Canada
}

\begin{abstract}
Chen, Y., and Fernando, W. G. D. 2006. Induced resistance to blackleg (Leptosphaeria maculans) disease of canola (Brassica napus) caused by a weakly virulent isolate of Leptosphaeria biglobosa. Plant Dis. 90:1059-1064.

Blackleg of canola is a disease complex of at least two fungal species: Leptosphaeria maculans and $L$. biglobosa. Isolates of L. biglobosa typically are weakly virulent or avirulent and are assigned to pathogenicity group 1 (PG-1). Isolates of L. maculans are highly virulent and encompass pathogenicity groups PG-2, PG-3, and PG-4. In greenhouse tests, percent lesion/leaf area (PLLA) on cotyledons of two Brassica napus cultivars, Westar and Invigor 2153, was smaller when L. biglobosa (PG-1) was either pre- or co-inoculated at $0,12,24$, and $48 \mathrm{~h}$ with virulent isolates of L. maculans in PG-2, PG-3, and PG-4. On six-leaf-stage plants of Westar, the PLLA declined significantly compared with the control when the lower leaves were treated with either PG-1 or salicylic acid, then challenged with a PG-2 isolate $24 \mathrm{~h}$ later. In addition, the activity of four enzymes (chitinase, $\beta$-1,3-glucanase, peroxidase, and phenylalanine ammonia lyase) was greatly enhanced at 48 and $72 \mathrm{~h}$ when cotyledons of Westar were inoculated first with PG-1 followed by PG-2 $24 \mathrm{~h}$ later, compared with a water control treatment. Field experiments conducted in 2003 and 2004 showed decreased blackleg severity in plants inoculated with PG-1 alone or prior to PG-2 compared with plants inoculated with PG-2 alone or prior to PG-1.
\end{abstract}

Canola (Brassica napus L.) is the second largest cash crop in Canada (4). Blackleg disease, caused by Leptosphaeria maculans (Desmaz.) Ces. \& De Not. (anamorph = Phoma lingam (Tode:Fr.) Desmaz.), is one of most economically important diseases of canola (21). In the past decade, canola production has expanded significantly worldwide and interest in the blackleg fungus, particularly its biology, pathogenicity, and control, has increased.

Blackleg of canola is a disease complex and consists of at least two types of fungal isolates: L. biglobosa (32), which is weakly virulent and classified as B group or type isolates; and L. maculans, which is aggressive, highly virulent, and classified as A group or type isolates (22). L. biglobosa typically causes Phoma leaf spots or superficial stem lesions, but L. maculans causes the more serious stem cankers. Based on the pathogenicity of isolates to three B. napus cultivars, Westar (susceptible), Glacier (Rlm 2 and $R \operatorname{lm} 3$ resistance genes), and Quinta (Rlml and Rlm4 resistance genes), the pathogen complex can be categorized into several pathogenicity

Corresponding author: W. G. D. Fernando

E-mail: D_Fernando@Umanitoba.ca

Accepted for publication 31 March 2006.

DOI: 10.1094/PD-90-1059

(C) 2006 The American Phytopathological Society groups (PGs) (26). L. biglobosa belongs to PG-1 and L. maculans comprises PG-2, PG-3, and PG-4. In addition to isolates of L. biglobosa, isolates in A group causing an incompatible reaction on resistant cultivars also are termed weakly virulent isolates of L. maculans (30).

Induced resistance to disease in plants is a state of enhanced plant defense capacity dependent on the host plant's physical and chemical barriers, activated by biotic or abiotic agents (3). Weakly virulent isolates have been shown to induce resistance in the host plant against virulent isolates in many pathosystems. Two avirulent races of Fusarium oxysporum f. sp. niveum induced resistance to Fusarium wilt of watermelon when challenged with a virulent race (24). Weakly virulent strains of Phytophthora infestans induced systemic resistance in potato to late blight (33) and avirulent isolates activated systemic resistance in broccoli against downy mildew (27). Nonpathogenic races of $F$. oxysporum f. sp. ciceris and $F$. oxysporum f. sp. lycopersici induced resistance to Fusarium wilt in chickpea and tomato $(16,20)$. Similarly, resistance in a susceptible mustard cultivar to the highly virulent Alternaria brassicae isolate $\mathrm{A}$ and moderately virulent isolate $\mathrm{C}$ was induced using the avirulent isolate $\mathrm{D}$ (35).

In the Brassica spp.-blackleg system, a rapid necrosis of guard cells in the leaves of Indian mustard occurred following inoculation of a resistant cultivar with an avirulent isolate of L. maculans (9). A hypersensitive reaction (HR) and an accumulation of phytoalexins were detected in Brassica spp. after inoculation with a weakly virulent isolate of $L$. maculans (28). An elicitin, cryptogein, and a weakly virulent isolate of blackleg pathogen both were capable of triggering HR on cotyledons of B. napus (30). Accumulation of pectin in the lumen of xylem vessels and the production of callose and lignin were confirmed to play a role in inhibiting systemic infection caused by $L$. maculans (19). In addition, induction of pathogenesis-related (PR) proteins, $\beta$-1,3-glucanase and chitinase, also has been documented (10).

The above studies were focused on the induction of HR in Brassica plants by preinoculation with a weakly virulent isolate. It might be beneficial, however, if weakly virulent isolates of L. biglobosa (PG-1) could trigger systemic acquired resistance (SAR) instead of the HR, because SAR can provide the plant with longer-lasting protection against a broad spectrum of pathogens.

SAR has been described in over 30 plant species (3) and elicitors of SAR comprise both biotic and abiotic agents. Mahuku et al. (23) reported SAR in canola to blackleg when a weakly virulent isolate was introduced $64 \mathrm{~h}$ prior to infection by a highly virulent isolate. In addition, the size of the lesions on the inoculated leaf and on neighboring leaves (above and below the inoculated leaf) and stem was reduced. However, the mechanism involved in this SAR still remains unknown and the performance of such SAR under field conditions has not been investigated.

In this study, we evaluated the ability of a weakly virulent isolate of L. biglobosa (PG-1) and the elicitor salicylic acid to induce resistance in $B$. napus against blackleg disease caused by virulent isolates of L. maculans (PG-2, PG-3, and PG4) in both the greenhouse and the field. The activity of four PR proteins (chitinase, $\beta$-1,3-glucanase, peroxidase [PO], and phenylalanine ammonia lyase [PAL]) also was measured.

\section{MATERIALS AND METHODS}

Preparation of inoculum. Isolates PL84-12 (PG-1) and PL86-12 (PG-2) were isolated from canola fields in Manitoba. Isolates PL89-18 (PG-3) and PL89-12 (PG-4) were from Australia. Each isolate was retrieved from mineral oil with myce- 
lia or pycnidia grown on slants of potato dextrose agar (PDA). After retrieving the isolates from storage, the cultures were grown on V8 agar medium $(200 \mathrm{ml}$ of V8 juice, $0.75 \mathrm{~g}$ of $\mathrm{CaCO}_{3}$, and $15 \mathrm{~g}$ of agar in $800 \mathrm{ml}$ of distilled $\mathrm{H}_{2} \mathrm{O}$ ) and then single spored. The isolates were passed once through canola cv. Westar (very susceptible to blackleg pathogen) to maintain their virulence and then grown on V8 for 14 days under continuous cool-white fluorescent light at $20^{\circ} \mathrm{C}$. Sporulating cultures were flooded with 10 to $15 \mathrm{ml}$ of sterile distilled water and gently scraped with a flamed glass rod to release spores from pycnidia. The pycnidiospores were harvested by filtering through sterilized Miracloth (Calbiochem) and centrifuged at $9,000 \mathrm{rpm}$ for $20 \mathrm{~min}$. The supernatant was decanted and the spore pellet was resuspended in approximately $1 \mathrm{ml}$ of sterile distilled water and stored as a concentrate at $-20^{\circ} \mathrm{C}$. Each pycnidiospore suspension was prepared at $1 \times 10^{7}$ spores $/ \mathrm{ml}$ and used in the inoculations.

Experiments on cotyledons. B. napus cvs. Westar (highly susceptible) and Invigor 2153 (Liberty Link, moderately susceptible) were seeded and grown in MetroMix in a growth chamber (16 and $21^{\circ} \mathrm{C}$, night and day, with a 16 -h photoperiod). Pycnidiospores of each isolate were inoculated onto wounded cotyledons 7 days after seeding. PL84-12 (PG-1) was co-inoculated, pre-inoculated, and postinoculated with each of the other three isolates, PL86-12 (PG-2), PL89-18 (PG-3), or PL89-12 (PG-4). Cotyledons treated solely with each of the PG isolates mentioned above served as controls. Pre- and post-inoculations were done at 12,24 , or $48 \mathrm{~h}$ relative to the initial inoculation. Each cotyledon was wounded once with a sterile needle and a $10-\mu l$ droplet of pycnidiospore suspension was pipetted onto the wound. The inoculated cotyledons were allowed to dry at least $12 \mathrm{~h}$ before the next application of watering. After inoculation, cotyledons were incubated in the same growth chamber. Twelve days after the last inoculation, percent lesion/leaf area (PLLA) on cotyledons was measured using the disease analysis computer program "Assess" (1), where PLLA = (lesion area/leaf area) $\times 100$. Seventy-two cotyledons were measured per treatment. The experiment was repeated once. Because the same isolates were used in all greenhouse experiments, they will be referred to only as PG-1, PG-2, PG-3, and PG-4 isolates hereafter.

Experiments on adult plants. B. napus cv. Westar was seeded and grown in MetroMix for 1 week. Seedlings were transplanted to one plant/pot $(15 \mathrm{~cm}$ in diameter by $14.5 \mathrm{~cm}$ high) containing a mix of soil:sand:peat (2:2:1, volume). The growth conditions were as described above. At the six-leaf stage, separate plants were wound inoculated with one of three reagents: sterile distilled $\mathrm{H}_{2} \mathrm{O}$, salicylic acid (SA, $10 \mathrm{mM}$ ), or PG-1 spore suspension on the lowest leaf of each plant. Twenty-four hours later, all plants were wound inoculated with $10 \mu \mathrm{l}$ of PG-2 spore suspension on a leaf just above the preinoculated leaf. The plants with initial inoculation of PG-1 also were inoculated with PG-2 on the upper leaves either at 48, 72, 96 or 120 h. Each treatment contained 50 plants with a total of 100 plants from two repetitions. PLLA on PG-2-inoculated leaves was measured 12 days after the inoculation of PG-2.

Assays for PR enzymes. One-week-old cotyledons of Westar were wound inoculated with a $10-\mu$ droplet of the following reagents: (i) sterile distilled $\mathrm{H}_{2} \mathrm{O}$, (ii) PG-1 spore suspension, (iii) PG-2 spore suspension, or (iv) PG-1 pre-inoculation followed by PG-2 $24 \mathrm{~h}$ later. After PG-2 inoculation, the cotyledons of each treatment were sampled at $0,6,12,24,48,72,96$, and 120 $\mathrm{h}$ for the estimation of activity of the defense-related enzymes chitinase, $\beta$-1,3glucanase, PO, and PAL. Each treatment consisted of 96 plants (two cotyledons/plant) and 12 plants per treatment were sampled each time.

Chitinase assay. Harvested cotyledons were homogenized immediately with liquid nitrogen using a pestle and mortar. Powdered sample $(1 \mathrm{~g})$ was ground in $1 \mathrm{ml}$ of $0.1 \mathrm{M}$ sodium citrate buffer $(\mathrm{pH} 5.0)$ at $4^{\circ} \mathrm{C}$. The homogenate was centrifuged at $4^{\circ} \mathrm{C}$ for $10 \mathrm{~min}$ at $10,000 \times g$. Determination of chitinase activity was based upon Boller and Mauch's protocol (7). Because chitinase activity was assayed by following the release of $\mathrm{N}$ acetyl glucosamine (GlcNac) from colloidal chitin, the enzyme activity was expressed as nanomoles of equivalent GlcNac per minute per milligram of protein.

Protein content in each extracted sample was calculated based on a standard curve constructed with bovine serum albumin (EC 232-936-2; Sigma Chemical Co., St. Louis, MO).

$\beta-1,3-G l u c a n a s e$ assay. Cotyledons were homogenized with liquid nitrogen using a pestle and mortar. The sample $(1 \mathrm{~g})$ was ground in $1 \mathrm{ml}$ of $0.05 \mathrm{M}$ sodium acetate buffer $(\mathrm{pH} 5.0)$ at $4^{\circ} \mathrm{C}$. The homogenate was allowed to react with $0.4 \%$ laminarin (EC 2327124; Sigma) for $10 \mathrm{~min}$ at $40^{\circ} \mathrm{C}$. The $\beta-1,3$-glucanase assay was based on the release of reducing glucose equivalent from laminarin as described by McCleary and Shameer (25); therefore, specific activity was expressed as micrograms of equivalent glucose per minute per milligram of protein.

PO assay. Fresh cotyledon tissue (1 g) was ground in $1 \mathrm{ml}$ of $0.1 \mathrm{M}$ phosphate buffer ( $\mathrm{pH}$ 7.0) using a cold pestle and mortar $\left(4^{\circ} \mathrm{C}\right)$. The homogenate was centrifuged at $15,000 \times g$ at $4^{\circ} \mathrm{C}$ for $15 \mathrm{~min}$ and the supernatant was used immediately for the enzyme assay. PO activity was deter- mined using pyrogallol (EC 201-762-9; Sigma) as the hydrogen donor and measuring the rate of color development spectrophotometrically at $420 \mathrm{~nm}$ at 30 -s intervals for $3 \mathrm{~min}$ (18). The PO activity was expressed as change in absorbance per minute per milligram of protein.

PAL assay. PAL activity was determined as the rate of conversion of Lphenylalanine to transcinnamic acid at the absorbance of $290 \mathrm{~nm}$ as described by Dickerson et al. (13). Cotyledon tissue (500 $\mathrm{mg}$ ) was homogenized in $1 \mathrm{ml}$ of cold 0.1 M sodium borate buffer ( $\mathrm{pH}$ 7.0) containing $0.1 \mathrm{~g}$ of insoluble polyvinyl-pyrrolidone (PVP) using a cold pestle and mortar $\left(4^{\circ} \mathrm{C}\right)$. The homogenate was centrifuged for $20 \mathrm{~min}$ at $15,000 \times g$ at $4^{\circ} \mathrm{C}$. The supernatant was used as the enzyme source for the assay. Samples containing $0.4 \mathrm{ml}$ of enzyme extract were incubated with $0.5 \mathrm{ml}$ of $0.1 \mathrm{M}$ borate buffer ( $\mathrm{pH} 8.8$ ) and $0.5 \mathrm{ml}$ of $12 \mathrm{mM}$ L-phenylalanine (EC 200-568-1; Sigma) for $30 \mathrm{~min}$ at $30^{\circ} \mathrm{C}$. The reaction was terminated by adding $0.5 \mathrm{ml}$ of $1 \mathrm{M}$ trichloroacetic acid. The enzyme blank contained $0.4 \mathrm{ml}$ of crude enzyme extract and $2.7 \mathrm{ml}$ of 0.1 $\mathrm{M}$ borate buffer ( $\mathrm{pH}$ 8.8). Absorbance was measured at $290 \mathrm{~nm}$. A molar extinction coefficient of $9,630 / \mathrm{min} / \mathrm{cm}$ was used for transcinnamic acid in $0.1 \mathrm{M}$ borate buffer (pH 8.8). The enzyme activity was expressed as $\mu \mathrm{mol}$ of cinnamic acid per minute per milligram of protein.

Field experiments. Field experiments were conducted at the Carman Research Station, Carman, Manitoba, Canada during the summers of 2003 and 2004.

Preparation of blackleg PG-1 and PG-2 inoculum was as described above. The cv. Westar was used for the field experiments. PG-1 pycnidiospore suspension $\left(1 \times 10^{7}\right.$ spores $/ \mathrm{ml}$ ) was sprayed at seedling emergence in order to have the weakly virulent isolate present prior to any colonization of the cotyledons by natural blackleg inoculum. PG-2 $\left(1 \times 10^{7}\right.$ spores $\left./ \mathrm{ml}\right)$ was inoculated $24 \mathrm{~h}$ later as well as at the two- to three-leaf stage. The eight treatments were as follows: (i) PG1: PG-1 inoculated alone on cotyledons; (ii) PG2: PG-2 inoculated alone on cotyledons; (iii) PG1+PG2 (1): PG-1 and PG-2 co-inoculated on cotyledons; (iv) PG1+PG2 (2): PG-1 and PG-2 co-inoculated at two- to three-leaf stage; (v) PG1-24h-PG2 (1): PG-1 inoculated first followed by PG-2 24 h later on cotyledons; (vi) PG1-24h-PG2 (2): PG-1 inoculated first followed by PG-2 $24 \mathrm{~h}$ later at two- to three-leaf stage; (vii) PG2-24hPG1 (1): PG-2 inoculated first followed by PG-1 24 h later on cotyledons; and (viii) PG2-24h-PG1 (2): PG-2 inoculated first followed by PG-1 $24 \mathrm{~h}$ later at two- to three-leaf stage. In 2004, the treatment PG2-24h-PG1 (2) was changed to a noninoculated blank control (background field inoculum). Each treatment was replicated three times. The plot size was 4 by $6 \mathrm{~m}^{2}$ with a 6-m buffer zone. The layout of the 
plots in the field was a completely random design (CRD). The plots were seeded on 26 May 2003 and 28 May 2004. Seeding density was $6.5 \mathrm{~kg} / \mathrm{h}$ (i.e., 24 lines [rows] within a 4-m width of each plot). Fertilizer 23-23-0 (N-P-K) at $80 \mathrm{~kg} / \mathrm{h}$ was applied once at seeding.

Blackleg disease severity (DS) was assessed on 100 plants per plot in 2003 (22 August) and 200 plants per plot in 2004 (30 August) before the Westar plants were fully ripe using a 0 -to-5 DS rating scale where $0=$ no diseased tissue visible in the cross-section of the stem base, $1=$ diseased tissue occupies 1 to $25 \%$ of crosssection, $2=$ diseased tissue occupies 26 to $50 \%$ of cross-section, $3=$ diseased tissue occupies 51 to $75 \%$ of cross-section, $4=$ diseased tissue occupies more than $75 \%$ of cross-section with little or no constriction of affected tissues, and $5=$ diseased tissue occupies $100 \%$ of cross-section with significant constriction of affected tissues, tissue dry and brittle, and plant dead.

The experimental data were analyzed using SAS (ver. 8, Cary, NC) statistical program and differences among treatments were evaluated by the linear model of analysis of variance (Fisher's least significant difference).

\section{RESULTS}

Greenhouse experiments on cotyledons. In order to determine whether variances between the two repetitions were homogeneous, Levene's test was employed. For both cultivars (Westar and Invigor 2153), the test was not significant at $P<0.05$, indicating that variances were homogeneous across repetitions. Therefore, data from the two trials were combined.

Treatments with blackleg isolates PG-2, PG-3, and PG-4 inoculated alone produced larger lesions than that of isolate PG-1 inoculated alone on cvs. Westar and Invigor 2153 (Table 1). Lesion size was smaller in all PG-1 pre-inoculated treatments compared with PG-2, PG-3, and PG-4 inoculated alone. The lesion sizes on Westar plants treated with PG-1 preceding PG-2, PG-3, or PG-4 at different time intervals, or PG-1 co-inoculated with each of virulent isolates, were not significantly different from PG-1 inoculated alone (Table 1). However, lesion sizes on Invigor 2153 plants inoculated with PG-1 preceding PG-4 at $24 \mathrm{~h}$ were significantly different from PG-1 isolate inoculated alone (Table 1). The lesion sizes in all PG-1 preinoculated treatments on Westar were always $<1 \%$. Lesion sizes on Westar plants treated with PG-2, PG-3, and PG-4 inoculated alone were 5- to 17-fold larger than the PG-1 pre-inoculated treatments. When PG-2, PG-3, or PG-4 were inoculated first, followed by PG-1, lesion size on both cvs. Westar and Invigor 2153 generally was equal to or larger than the corresponding virulent isolates inoculated alone. The lesion size of the treatment with PG-4 inoculated prior to PG-1 on Westar plants became larger with time $(8.5,11.8$, and $14.1 \%$ at 12,24 , and $48 \mathrm{~h}$, respectively). Similar results were obtained on cv. Invigor 2153.

Greenhouse experiments on adult plants. The PLLA in $\mathrm{H}_{2} \mathrm{O}$ pre-application treatment followed by $\mathrm{PG}-2$ on upper leaves was significantly higher than that of the treatments with SA or PG-1 preapplication (Fig. 1). The lesion size of the SA pre-treatment was not significantly different from the lesion size in PG-1 pretreatments. The PLLAs of PG-1 preinoculated followed by PG-2 on the upper leaves at different time intervals (up to 120 h) were not different from each other.

PR enzyme activity. All four treatments $\left(\mathrm{H}_{2} \mathrm{O}, \mathrm{PG}-1, \mathrm{PG}-2\right.$ inoculated alone, and
PG-1 pre-inoculated followed by PG-2 24 $h$ later [PG1-24h-PG2]) showed an increase in chitinase activity that declined by $96 \mathrm{~h}$ after inoculation (Fig. 2A). The increase in chitinase activity in treatment PG1-24h-PG2 was much higher after inoculation compared with the other three treatments. Peak chitinase activity was at $96 \mathrm{~h}$, and GlcNac reached 1,270 $\mathrm{nmol} / \mathrm{min} / \mathrm{mg}$ of protein, which was sixfold higher than that of the $\mathrm{H}_{2} \mathrm{O}$ treatment (GlcNac at $70 \mathrm{nmol} / \mathrm{min} / \mathrm{mg}$ of protein).

During the first $48 \mathrm{~h}$, the activity of $\beta$ 1,3-glucanase was at low levels in all four treatments (Fig. 2B). Thereafter, the activity of $\beta$-1,3-glucanase in the PG1-24h-PG2 treatment began to increase and reached a peak of the equivalent of glucose at 6,200 $\mu \mathrm{g} / \mathrm{min} / \mathrm{mg}$ of protein by $120 \mathrm{~h}$ after inoculation, which was fivefold higher than that

Table 1. Relative sizes of leaf lesions caused by Leptosphaeria maculans pathogenicity group (PG)-2, PG-3, and PG-4 isolates reduced by pre- or co-inoculation with L. biglobosa (PG-1) isolate in canola cvs. Westar and Invigor $2153^{y}$

\begin{tabular}{|c|c|c|c|c|c|c|}
\hline Cultivars & Treatment $^{\mathrm{z}}$ & Time (h) & PG-1 & PG-2 & PG-3 & PG-4 \\
\hline \multicolumn{7}{|l|}{ Westar } \\
\hline & Single isolate & $\ldots$ & $0.4 \mathrm{ij}$ & $1.9 \mathrm{gh}$ & $3.6 \mathrm{rf}$ & $6.6 \mathrm{~d}$ \\
\hline & Co-inoculated & $\ldots$ & $\ldots$ & $0.3 \mathrm{ij}$ & $1.5 \mathrm{ghi}$ & $0.4 \mathrm{ij}$ \\
\hline & Pre-inoculated & 12 & $\ldots$ & $0.4 \mathrm{ij}$ & $0.3 \mathrm{ij}$ & $0.3 \mathrm{ij}$ \\
\hline & & 24 & $\ldots$ & $0.4 \mathrm{ij}$ & $0.4 \mathrm{ij}$ & 0.8 hij \\
\hline & & 48 & $\ldots$ & $0.5 \mathrm{ij}$ & $0.2 \mathrm{ij}$ & $0.1 \mathrm{j}$ \\
\hline & Post-inoculated & 12 & $\ldots$ & $2.6 \mathrm{fg}$ & $3.2 \mathrm{ef}$ & $8.5 \mathrm{c}$ \\
\hline & & 24 & $\ldots$ & $4.0 \mathrm{e}^{\mathrm{C}}$ & $6.8 \mathrm{~d}$ & $11.8 \mathrm{~b}$ \\
\hline & & 48 & $\ldots$ & $6.0 \mathrm{~d}$ & $6.2 \mathrm{~d}$ & $14.1 \mathrm{a}$ \\
\hline \multicolumn{7}{|l|}{ Invigor 2153} \\
\hline & Single isolate & $\ldots$ & $0.5 \mathrm{k}$ & $2.1 \mathrm{fgh}$ & $2.5 \mathrm{efg}$ & $5.4 \mathrm{c}$ \\
\hline & Co-inoculated & $\ldots$ & $\ldots$ & $0.1 \mathrm{k}$ & $1.1 \mathrm{ijk}$ & $0.5 \mathrm{jk}$ \\
\hline & Pre-inoculated & 12 & $\ldots$ & $0.2 \mathrm{k}$ & $0.2 \mathrm{k}$ & $0.5 \mathrm{jk}$ \\
\hline & & 24 & $\ldots$ & $0.3 \mathrm{k}$ & $0.5 \mathrm{jk}$ & $1.8 \mathrm{ghi}$ \\
\hline & & 48 & $\ldots$ & $0.3 \mathrm{k}$ & $0.1 \mathrm{k}$ & $0.2 \mathrm{k}$ \\
\hline & Post-inoculated & 12 & $\ldots$ & $1.5 \mathrm{hij}$ & $2.3 \mathrm{fgh}$ & $4.5 \mathrm{~d}$ \\
\hline & & 24 & $\ldots$ & $2.8 \mathrm{ef}$ & $3.3 \mathrm{e}^{\circ}$ & $8.2 \mathrm{~b}$ \\
\hline & & 48 & $\ldots$ & $2.2 \mathrm{fgh}$ & $2.7 \mathrm{efg}$ & $11.3 \mathrm{a}$ \\
\hline
\end{tabular}

y Lesion size was defined as percent lesion/leaf area (PLLA) and PLLA values are the means of two repetitions. Westar is highly susceptible and Invigor 2153 is moderately susceptible to blackleg. Data with different letters within a column or row in same cultivar are significantly different (Duncan's multiple range test, $P<0.01$ ). Critical range is 1.37 to 1.43 in Westar and 1.07 to 1.11 in Invigor 2153.

z Pycnidiospores $\left(1 \times 10^{7}\right.$ spores/ml) of L. biglobosa isolate PG-1 (PL84-12) and L. maculans isolates PG-2 (PL86-12), PG-3 (PL89-18), or PG-4 (PL89-12) were inoculated onto cotyledons. PG-1 was co-, pre-, and post-inoculated with each of the other three isolates. Pre- and post-inoculations were done at 12,24 , or $48 \mathrm{~h}$ following the initial treatment.

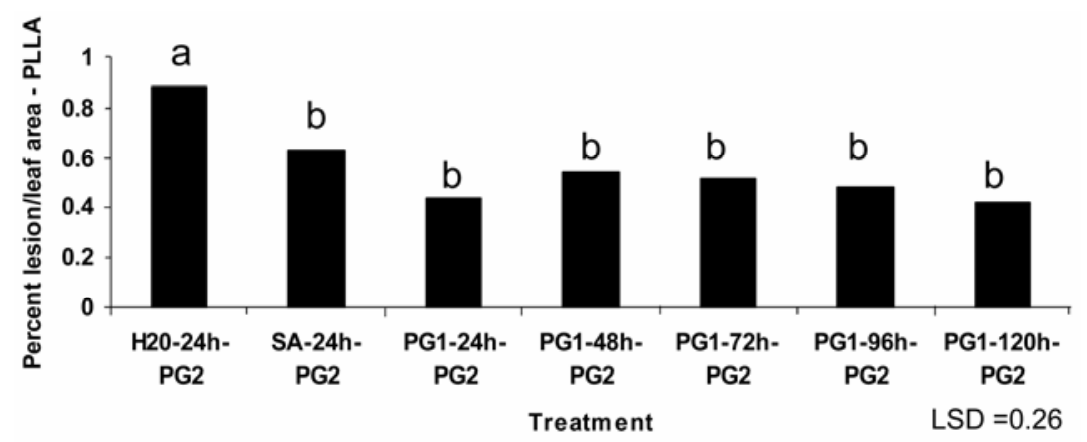

Fig. 1. Relative lesion size on six-leaf stage canola plants pre-inoculated with salicylic acid (SA) or Leptosphaeria biglobosa isolate PL84-12 (pathogenicity group [PG]-1) on lower leaves, and followed by inoculation of L. maculans isolate PL86-12 (PG-2) at 24, 48, 72, 96, or $120 \mathrm{~h}$ on upper leaves. Treatments with the same letter are not significantly different according to least significant difference (LSD; $P<0.05)$. 

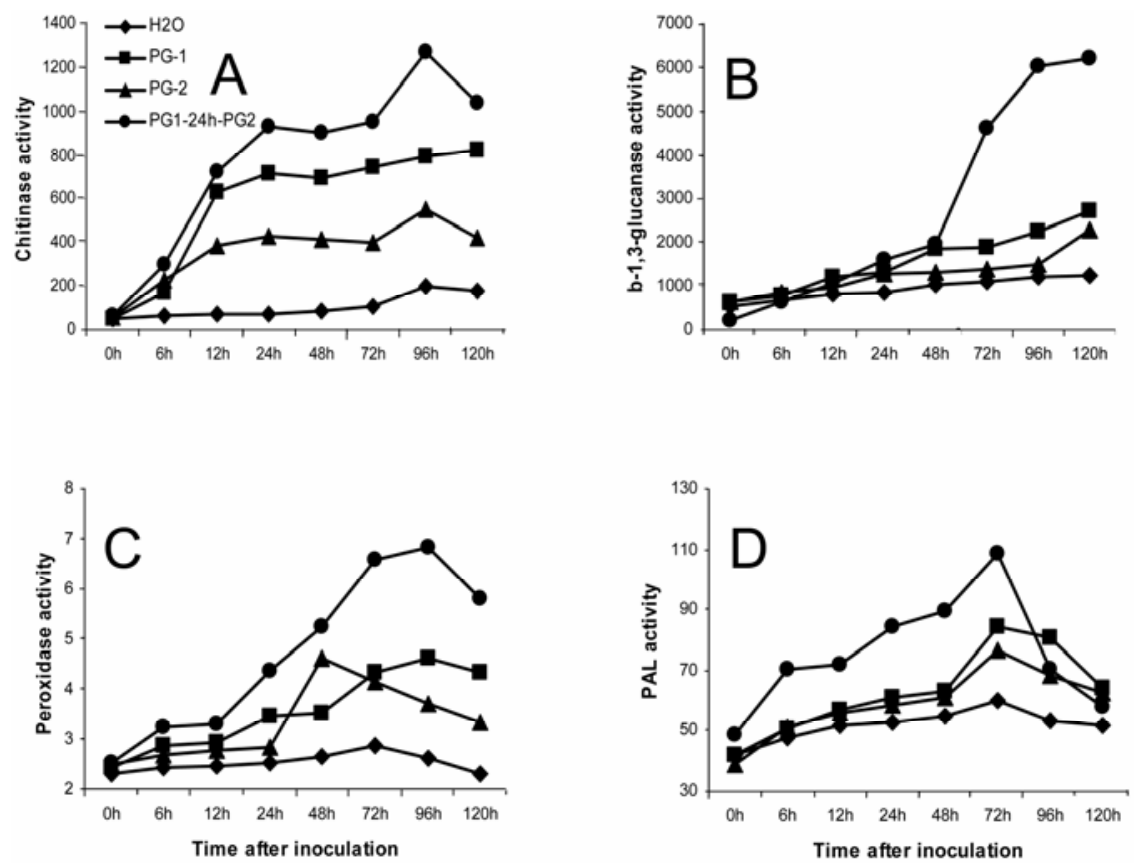

Fig. 2. Changes of defense enzyme activity in canola cv. Westar cotyledons treated with $\mathrm{H}_{2} \mathrm{O}$ or inoculated with Leptosphaeria biglobosa isolate PL84-12 (pathogenicity group [PG]-1), L. maculans isolate PL86-12 (PG-2), or PG-1 $24 \mathrm{~h}$ prior to PG-2 at time intervals of 0, 6, 12, 24, 48, 72, 96, and $120 \mathrm{~h}$. A, Chitinase activity ( $\mathrm{N}$ acetyl glucosamine in $\mathrm{nmol} / \mathrm{min} / \mathrm{mg}$ of protein); $\mathbf{B}, \beta-1,3$-glucanase activity (glucose in $\mu \mathrm{g} / \mathrm{min} / \mathrm{mg}$ of protein); C, peroxidase activity (change in absorbance $/ \mathrm{min} / \mathrm{mg}$ of protein); and $\mathbf{D}$, phenylalanine ammonia lyase (PAL) activity (cinnamic acid in $\mu \mathrm{mol} / \mathrm{min} / \mathrm{mg}$ of protein).
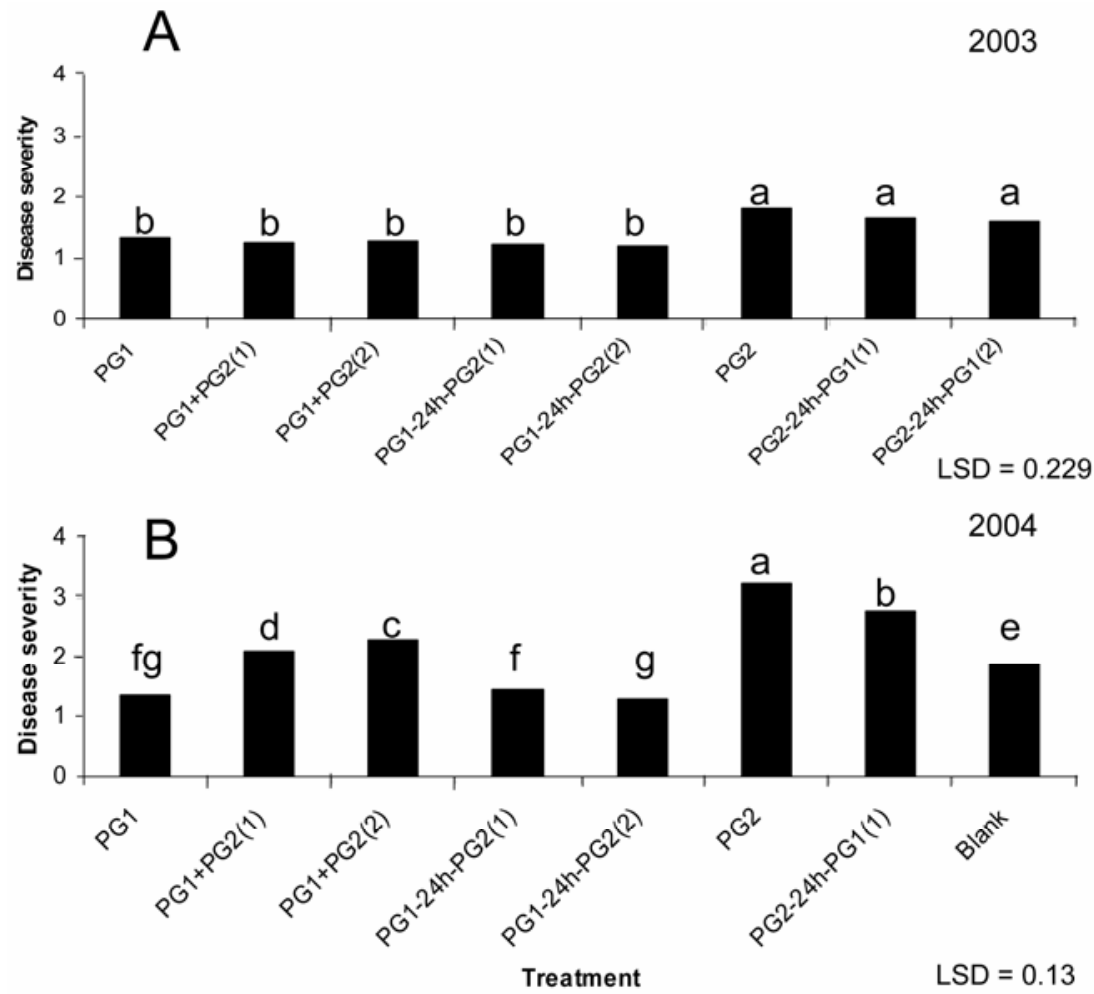

Fig. 3. Disease severity caused by a virulent isolate of Leptosphaeria maculans (PL86-12; pathogenicity group [PG]-2) on canola cv. Westar in the presence or absence of a weakly virulent isolate of $L$. biglobosa (PL84-12; PG-1) in field trials conducted in Carman, Manitoba in A, 2003 and B, 2004. PG1 = PG-1 inoculated alone on cotyledon, PG1+PG2 (1) = PG-1 and PG-2 co-inoculated on cotyledon, PG1+PG2 (2) = PG-1 and PG-2 co-inoculated at two- to three-leaf stage, PG1-24h-PG2 (1) = PG1 preceded PG-2 by $24 \mathrm{~h}$ on cotyledon, PG1-24h-PG2 (2) = PG-1 preceded PG-2 by $24 \mathrm{~h}$ at two- to three-leaf stage, PG2 = PG-2 inoculated alone on cotyledon, PG2-24h-PG1 (1) = PG-2 preceded PG-1 by $24 \mathrm{~h}$ on cotyledon, and PG2-24h-PG1 (2) = PG-2 preceded PG-1 by $24 \mathrm{~h}$ at two- to three-leaf stage. Treatments followed by the same letter are not significantly different $(P<0.05)$. Treatments in $\mathbf{B}$ are the same as $\mathbf{A}$, except blank = noninoculated control. 
The co-infection and coexistence of highly virulent and weakly virulent strains in a single blackleg leaf lesion were confirmed both by culture morphology and polymerase chain reaction detection (23). However, the time it takes for the defense response during the interaction between the highly virulent and weakly virulent isolates is important. On cotyledons, disease reduction was noticed only in treatments when PG-1 was pre- or co-inoculated with PG-2, PG-3, and PG-4 isolates. When PG-2, PG-3, and PG-4 were inoculated first, followed by PG-1, an increased lesion size occurred in some treatments. This might have resulted from virulent isolates weakening the plant's defense and then facilitating PG-1 colonization, causing further infection. This also may occur under natural field conditions; however, the weakly virulent isolate is known to cause infections later in the season (36).

According to Baker (3), SAR is a general, nonspecific defense response in plants that develops after localized attack by viral, bacterial, or fungal pathogens. PG-1 isolate of L. biglobosa used in this study is considered weakly virulent because it causes superficial lesions on canola plants. Roussel et al. (30) observed that wound inoculation with an incompatible isolate on a resistant cultivar induces lignifications in leaf vascular bundles, resulting in an HR. In the greenhouse, PG-1-induced resistance on the cotyledons showed characteristics similar to HR because inoculation was on the same wounding site. Wounding may be a potential causal factor of HR; however, from our experiment, it was clearly evident that reduced disease was seen in co-inoculated plants compared with PG-2, PG-3, or PG-4 inoculated individually with wounding. Sequeira (31) noted that the role of wounding in induced resistance has not been determined with precision. Felton et al. (14) reported that a separate signaling pathway involving jasmonic acid is involved in systemic responses to wounding and insect herbivory. Working with weakly aggressive isolates of Bipolaris sorokiniana, Peltonen (29) was able to show that wounding alone did not induce PAL.

Inoculations with PG-1 at the six-leaf stage provided some evidence for SAR. When plants were pretreated with the PG-1 isolate on lower leaves and then treated with PG-2 on the upper leaves, resistance was observed. SA, a well known elicitor of SAR, provided a similar defense response to that of PG-1 treatment, indicating that PG-1 may be involved in inducing the SA pathway.

If SAR occurs in the plants, defenserelated enzymes will be activated (34). Biles and Martyn (6) found that PO isozymes were greatly enhanced in watermelon seedlings inoculated with an avirulent race of $F$. oxysporum f. sp. niveum. The increase in activity of chitinase, $\beta-1,3$ - glucanase, PO, and PAL in plants treated with PG-1 (pre-application) indicated that the defense genes coding for these enzymes are induced by the stimulus PG-1 isolate through a signal pathway, probably the SA pathway. Chitinase and $\beta-1,3-$ glucanase are lytic enzymes potentially acting on cell walls of organisms that have chitin and glucan as their cell wall component and they can be induced in the plant system (25). PO represents a component of early response in plants to pathogen attack and plays a key role in the biosynthesis of lignin, which limits the extent of pathogen spread (5). PAL is the principal enzyme involved in the phenyl propanoid pathway and promotes the production of phytoalexins, terpenes, and phenolic substances leading to formation of lignin with the help of POs (12).

Two years of field trials suggested that PG-1 inoculated alone or $24 \mathrm{~h}$ prior to PG2 inoculation significantly reduced disease severity by $L$. maculans.

Both ascospores and pycnidiospores of L. maculans can be the primary inoculum source of blackleg disease; however, ascospores are more important in causing yield loss by causing stem cankers during the growth period from cotyledons to eightleaf stage (17). Both weakly virulent and highly virulent isolates exist in western Canada (36). However, weakly virulent isolates typically appear late in the season during pod maturation (36) and they can have compatible interactions on aging host tissue, causing infections under high temperatures (2). This may be why PG-1induced resistance has not been observed in farmer's fields. The application of PG-1 pycnidiospores prior to the natural infection by PG-2 might effectively induce resistance and significantly decrease infection and disease caused by the virulent isolates.

Induced resistance is a manageable trait and is unlikely to break down with a change in pathogen populations. This is important particularly at a time when the blackleg pathogen population seems to be changing in western Canada and in the north-central United States $(8,11,15)$. Moreover, induced resistance to blackleg can be functional even in susceptible canola cultivars; this could benefit both farmers and canola breeders greatly because many currently used Canadian cultivars lack resistance to the highly virulent PG-3 and PG-4 isolates (W. G. D. Fernando and Y. Chen, unpublished data).

\section{ACKNOWLEDGMENTS}

We thank the Natural Sciences and Engineering Research Council of Canada (NSERC) and the Canola Council of Canada for financial assistance, P. Parks and A. Iverson for assistance with the field work, S. Nakkeeran for his help in assays for the PR enzymes, and M. Ballance for critically evaluating the manuscript.

\section{LITERATURE CITED}

1. ASSESS 2002. Image Analysis Software for Plant Disease Quantification. The American
Phytopathological Society, American Phytopathological Society Press, St. Paul, MN.

2. Badawy, H. M. A., Kakau, J., and Hopper, H. H. 1992. Temperature and aging of host tissue affect the interactions between different oilseed rape cultivars and pathotype groups of Leptosphaeria maculans. J. Phytopathol. 134:255-263.

3. Baker, C. 2000. Systemic acquired resistance. Pages 198-217 in: Molecular Plant Pathology. Annual Plant Reviews, Vol. 4. M. Dickinson and J. Beynon, eds. Sheffield Academic Press, Sheffield, U.K.

4. Beckman, C. 2004. Profile of the Canadian oilseeds sector: part 1. Bi-weekly Bulletin, Agriculture and Agri-Food Canada. Vol. 17: No. 13.

5. Bernards, M. A., Summerhurst, D. K., and Razem, F. A. 2004. Oxidases, peroxidases and hydrogen peroxide: The suberin connection. Phytochem. Rev. 3:113-126.

6. Biles, C. L., and Martyn, R. D. 1993. Peroxidase, polyphenoloxidase, and shikimate dehydrogenase isozymes in relation to tissue type, maturity and pathogen induction of watermelon seedlings. Plant Physiol. Biochem. 31:499-506.

7. Boller, T., and Mauch, F. 1988. Colorimetric assay for chitinase. Method Enzymol. 161:430-435.

8. Bradley, C. A., Parks, P. S., Chen, Y., and Fernando, W. G. D. 2005. First report of pathogenicity groups 3 and 4 of Leptosphaeria maculans on canola in North Dakota. Plant Dis. 89:776.

9. Chen, C. Y., and Howlett, B. J. 1996. Rapid necrosis of guard cells is associated with the arrest of fungal growth in leaves of Indian mustard (Brassica juncea) inoculated with avirulent isolates of Leptosphaeria maculans. Physiol. Mol. Plant Pathol. 48:73-81.

10. Chen, C. Y., and Seguin-Swartz, G. 1997. The use of a $\beta$-glucuronidase-marked isolate of Leptosphaeria maculans to study the reaction of crucifers to the blackleg fungus. Can. J. Plant Pathol. 19:327-330.

11. Chen, Y., and Fernando, W. G. D. 2005. First report of canola blackleg caused by pathogenicity group 4 of Leptosphaeria maculans in Manitoba. Plant Dis. 89:339.

12. Cools, H. J., and Ishii, H. 2002. Pre-treatment of cucumber plants with acibenzolar-S-methyl systemically primes a phenylalanine ammonia lyase gene (PAL1) for enhanced expression upon attack with a pathogenic fungus. Physiol. Mol. Plant Pathol. 61:273-280.

13. Dickerson, D. P., Pascholati, S. F., Hagerman, A. E., Butler, L. G., and Nicholson, R. L. 1984. Phenylalanine ammonia-lyase and hydroxycinnamate-CoA ligase in maize mesocotyls inoculated with Helminthosporium maydis or Helminthosporium carbonum. Physiol. Plant Pathol. 25:111-123.

14. Felton, G. W., Korth, K. L., Bi, J. L., Wesley, S. V., Huhman, D. V., Mathews, M. C., Murphy, J. B., Lamb, C., and Dixon, R. A. 1999. Inverse relationship between systemic resistance of plants to microorganisms and to insect herbivory. Curr. Biol. 9(6):317-320.

15. Fernando, W. G. D., and Chen, Y. 2003. First report on the presence of Leptosphaeria maculans pathogenicity group-3, the casual agent of blackleg of canola in Manitoba. Plant Dis. $87: 1268$.

16. Fuchs, J. G., Moenne-Loccoz, Y., and Defago, G. 1999. Ability of nonpathogenic Fusarium oxysporum Fo47 to protect tomato against Fusarium wilt. Biol. Control 14:105-110.

17. Hall, R. 1992. Epidemiology of blackleg of oilseed rape. Can. J. Plant Pathol. 14:46-55.

18. Hammerschmidt, R., Nuckles, E. M., and Kuc, J. 1982. Association of enhanced peroxidaseactivity with induced systemic resistance of cucumber to Colletotrichum lagenarium. 
Physiol. Plant Pathol. 20:73-82.

19. Hammond, K. E., Lewis, B. G., and Musa, T. M. 1985. A systemic pathway in the infection of oilseed rape plants by Leptosphaeria maculans. Plant Pathol. 34:557-565.

20. Hervas, A., Traperocasas, J. L., and Jimenezdiaz, R. M. 1995. Induced resistance against Fusarium wilt of chickpea by nonpathogenic races of Fusarium oxysporum f. sp. ciceris and nonpathogenic isolates of Fusarium oxysporum. Plant Dis. 79:1110-1116.

21. Howlett, B. J. 2004. Current knowledge of the interaction between Brassica napus and Leptosphaeria maculans. Can. J. Plant Pathol. 26:245-252.

22. Howlett, B. J., Idnurm, A., and Pedras, M. S. C. 2001. Leptosphaeria maculans, the causal agent of blackleg disease of Brassicas. Fungal Genet. Biol. 33:1-14.

23. Mahuku, G. S., Hall, R., and Goodwin, P. H. 1996. Co-infection and induction of systemic acquired resistance by weakly and highly virulent isolates of Leptosphaeria maculans in oilseed rape. Physiol. Mol. Plant Pathol. 49:61-72.

24. Martyn, R. D., Biles, C. L., and Dillard, E. A. 1991. Induced resistance to Fusarium wilt of watermelon under simulated field conditions. Plant Dis. 75:874-877.

25. McCleary, B. V., and Shameer, I. 1987. Assay of malt beta-glucanase using azo-barley glucan-an improved precipitant. J. Inst. Brew. 93:87-90.

26. Mengistu, A., Rimmer, S. R., Koch, E., and Williams, P. H. 1991. Pathogenicity grouping of isolates of Leptosphaeria maculans on Brassica napus cultivars and their disease reaction profiles on rapid-cycling Brassicas. Plant Dis. 75:129-1282.

27. Monot, C., Pajot, E., Le Corre, D., and Silue, D. 2002. Induction of systemic resistance in broccoli (Brassica oleracea var. botrytis) against downy mildew (Peronospora parasitica) by avirulent isolates. Biol. Control 24:75-81.

28. Pedras, M. S. C., Nycholat, C. M., Montaut, S., Xu, Y. M., and Khan, A. Q. 2002. Chemical defenses of crucifers: elicitation and metabolism of phytoalexins and indole-3-acetonitrile in brown mustard and turnip. Phytochemistry 59:611-625.

29. Peltonen, S. 1998. Responses of barley and wheat to pathogens, non-pathogens and wounding as indicated by induced phenylalanine-lyase activity. Acta Agric. Scand. B 48(3):184-191.

30. Roussel, S., Nicole, M., Lopez, F., Ricci, P., Geiger, J. P., Renard, M., and Brun, H. 1999. Leptosphaeria maculans and cryptogein in- duce similar vascular responses in tissues undergoing the hypersensitive reaction in Brassica napus. Plant Sci. 144:17-28.

31. Sequeira, L. 1983. Mechanism of induced resistance in plants. Annu. Rev. Microbiol 37:51-79.

32. Shoemaker, R. A., and Brun, H. 2001. The teleomorph of the weakly aggressive segregate of Leptosphaeria maculans. Can. J. Bot. 79:412-419.

33. Stromberg, A. 1995. Systemically induced resistance in potato cultivars with different degree of resistance to late blight caused by Phy tophthora infestans (Mont) de Bary. J. Phytopathol. 143:27-31.

34. Van Loon, L. C. 1997. Induced resistance in plants and the role of pathogenesis-related proteins. Eur. J. Plant Pathol. 103:753-765.

35. Vishwanath, Kolte, S. J., Singh, M. P., and Awasthi, R. P. 1999. Induction of resistance in mustard (Brassica juncea) against Alternaria black spot with an avirulent Alternaria brassicae isolate-D. Eur. J. Plant Pathol. 105:217-220.

36. West, J. S., Kharbanda, P. D., Barbetti, M. J. and Fitt, B. D. L. 2001. Epidemiology and management of Leptosphaeria maculans (Phoma stem canker) on oilseed rape in Australia, Canada and Europe. Plant Pathol. 50:1027. 